\title{
From 1900 to 2000: History of Earthworm taxonomy in the North and Northeast of Brazil and its current distribution in Brazilian Biomes
}

\section{Sandriel Costa Sousa ${ }^{1,3}$; Luis Manuel Hernández-García, ${ }^{1,4}$ \& Martin Lindsey Christoffersen ${ }^{2,5}$}

${ }^{1}$ Universidade Estadual do Maranhão (UEMA), Programa de Pós-Graduação em Agroecologia. São Luís, MA, Brasil.

${ }^{2}$ Universidade Federal da Paraíba (UFPB), Centro de Ciências Exatas e da Natureza (CCEN), Departamento de Sistemática e Ecologia (DSE). João Pessoa, PB, Brasil.

${ }^{3}$ ORCID: http://orcid.org/0000-0001-6346-6682. E-mail: sandriel04@gmail.com

${ }^{4}$ ORCID: http://orcid.org/0000-0003-1478-4953. E-mail:hglm72@gmail.com

${ }^{5}$ ORCID: http://orcid.org/0000-0001-8108-1938. E-mail: mlchrist@dse.ufpb.br

\begin{abstract}
One of the initial milestones for earthworm taxonomy was the work of Michaelsen (1900), "Das Tierreich Oligochaeta". During this period only two exotic species of the genus Amynthas were recorded for the North and Northeast of Brazil. A century has passed and little is known about the taxonomy of earthworms in these two regions and the distribution of these organisms in Brazilian Biomes. The Brazilian territory is divided into six large biomes, Amazonian, Caatinga, Cerrado, Atlantic Forest, Pampa, and Wetlands. Little is known about the distribution of earthworms in these environments. This article provides a review of the literature on the progress of taxonomy in northern and northeastern Brazil over a century and provides the current distribution of earthworms in Brazilian biomes. In the first four decades the taxonomy has advanced at a slow pace, with only 19 new species recorded. With the beginning of Gilberto Righi's work, earthworm taxonomy has advanced significantly. After Righi's death in 1999, taxonomy in the North and Northeast has only begun breathing again within the past two years, in which the description of nine new species and two new genera have appeared. There are currently 174 species distributed in thirteen of the sixteen states that make up the North and Northeast regions of Brazil. Regarding distribution, the Amazon, Mata Atlantica and Cerrado biomes stand out for being the most diverse in genera and species, while the Caatinga, Pampa and Pantanal biomes are less diversified. In addition, the Caatinga and Pampa are the only biomes having more exotic species than native species.
\end{abstract}

Key-Words. Biodversity; Gilberto Righi; Hotspots; Invertebrates.

\begin{abstract}
Resumo. Um dos marcos iniciais para a taxonomia de minhocas foi o trabalho de Michaelsen (1900) Das Tierreich Oligochaeta. Nesse período, apenas duas espécies exóticas do gênero Amynthas foram registradas no Norte e Nordeste do Brasil. Um século se passou e pouco se sabe sobre a taxonomia das minhocas nessas duas regiões e a distribuição desses organismos nos Biomas brasileiros. 0 território brasileiro é dividido em seis grandes Biomas, Amazônia, Caatinga, Cerrado, Mata Atlântica, Pampa e Pantanal. Pouco se sabe sobre a distribuição de minhocas nesses ambientes. Este artigo fornece uma revisão da literatura sobre o progresso da taxonomia no Norte e Nordeste do Brasil ao longo de um século e qual é a atual distribuição de minhocas nos Biomas brasileiros. Nas primeiras quatro décadas, a taxonomia avançou em ritmo lento, com apenas 19 novas espécies registradas. Com o início dos trabalhos de Gilberto Righi, a taxonomia das minhocas avançou significativamente. Após a morte de Righi, em 1999, a taxonomia no Norte e Nordeste só começou a respirar novamente nos últimos dois anos, nos quais houve a descrição de nove novas espécies e dois novos gêneros. Atualmente, existem 174 espécies distribuídas em treze dos dezesseis estados que compõem as regiões Norte e Nordeste do Brasil. Em relação à distribuição, os Biomas Amazônia, Mata Atlântica e Cerrado se destacam por serem os mais biodiversos em gêneros e espécies, enquanto os Biomas Caatinga, Pampa e Pantanal são menos diversificados. Além disso, Caatinga e Pampa são os únicos biomas que possuem mais espécies exóticas que espécies nativas.
\end{abstract}

Palavras-Chave. Biodversidade; Gilberto Righi; Hotspots; Invertebrados. 


\section{INTRODUCTION}

The first major work on worm systematics was published in 1900 by Michaelsen, where he recognized 11 families and 11 subfamilies, which contained 152 genera and about 1,200 species.

Before Michaelsen, one of the main references to earthworms was Charles Darwin's book (1881) "The formation of vegetable mould through the action of worms with observations on their habits", which was largely responsible for changing the way these organisms were viewed by the population, that considered worms to be pests harmful to the soil (Walton, 1928).

In Brazil, the most comprehensive and representative work involving earthworms was published in 2007 by Brown \& James, which addressed the biology, ecology and distribution of earthworms, being the first national work to relate the distribution of these organisms with Brazilian Biomes.

In general, Biome can be defined as "a homogeneous area that is arranged on a regional scale, being influenced by the same processes of formation" (Coutinho, 2006). In Brazil there are six biomes: Amazonian, Caatinga, Cerrado, Atlantic Forest, Wetlands, and Pampa. Importantly, all of these biomes suffer from some kind of anthropogenic pressure (Nascimento \& Ribeiro, 2017), which can cause or accelerate biodiversity loss (Silva et al., 2018). Among the groups most susceptible to this loss of biodiversity are earthworms, organisms essential for soil biology (Ojha \& Devkota, 2014) and considered to be ecosystem engineers (Jones et al., 1994).

However, even with the comprehensive work of Brown \& James (2007), data on earthworm taxonomy and distribution are still scarce and sometimes outdated. Much of this scarcity of data is the result of the low number of active specialists capable of developing work

Table 1. Earthworm species recorded in the period 1901-1940 in the North and Northeast of Brazil.

\begin{tabular}{|c|c|c|c|c|}
\hline Species & State & Native/Exotic & Author & Reference \\
\hline Aptodrilus salathei & $\mathrm{AM}, \mathrm{RR}$ & Native & Michaelsen, 1934 & Michaelsen, 1934 \\
\hline Andiorrhinus pictus & $\mathrm{AM}$ & Native & Michaelsen, 1926 & Michaelsen, 1926 \\
\hline Andiorrhinus planaria & $\mathrm{AM}$ & Native & Michaelsen, 1934 & Michaelsen, 1934 \\
\hline Andiorrhinus proboscideus & PA & Native & Cernosvitov, 1939 & Cernosvitov, 1939 \\
\hline Andiorrhinus rubescens & AM & Native & Michaelsen, 1926 & Michaelsen, 1926 \\
\hline Diachaeta carsevenica & AP & Native & Cernosvitov, 1934 & Cernosvitov, 1934 \\
\hline Dichogaster bolaui & $\mathrm{AM}, \mathrm{AP}$ & Exotic & Michaelsen, 1891 & $\begin{array}{l}\text { Michaelsen, 1927; } \\
\text { Cernosvitov, } 1935\end{array}$ \\
\hline Enantiodrilus borellii & $\mathrm{AM}, \mathrm{PA}$ & Native & Cognetti, 1902 & Michaelsen, 1927 \\
\hline Glyphidrilocrius ehrhardti & $\mathrm{AM}$ & Native & Michaelsen, 1926 & Michaelsen, 1926 \\
\hline Martiodrilus ohausi & $\mathrm{AM}$ & Native & Michaelsen, 1917 & Michaelsen, 1917 \\
\hline Neogaster americanus & AP & Native & Cernosvitov, 1934 & Cernosvitov, 1934 \\
\hline Paulistus taunayi & $B A$ & Native & Michaelsen, 1926 & Michaelsen, 1926 \\
\hline Rhinodrilus annulatus & AP & Native & Cernosvitov, 1934 & Cernosvitov, 1934 \\
\hline Rhinodrilus garbei & $\mathrm{PE}$ & Native & Michaelsen, 1926 & Michaelsen, 1926 \\
\hline Rhinodrilus lakei & $\mathrm{AM}, \mathrm{RR}$ & Native & Michaelsen, 1934 & Michaelsen, 1934 \\
\hline Rhinodrilus longus & AP & Native & Cernosvitov, 1934 & Cernosvitov, 1934 \\
\hline Rhinodrilus romani & $\mathrm{AM}$ & Native & Michaelsen, 1928 & Michaelsen, 1928 \\
\hline Wegeneriona brasiliana & PA & Native & Cernosvitov, 1939 & Cernosvitov, 1939 \\
\hline Wegeneriona michaelseni & AP & Native & Cernosvitov, 1934 & Cernosvitov, 1934 \\
\hline
\end{tabular}

in this area of research (Fragoso et al., 2003). Given this context, the present work provides a bibliographical review on the history of earthworm taxonomy in North and Northeast Brazil and updates the distribution of this group in the Brazilian Biomes.

\section{METHODOLOGY}

The present work is the result of a literature review. The story was divided into four periods. The first corresponds to the year 1900, the second to the period 1901-1940, the third to 1941-1980, and the fourth to the period spans the years 1981-2018. Two letters were used to abbreviate the northern and northeastern states $(A C=$ Acre; $A M=$ Amazonas; $A P=$ Amapá; $B A=$ Bahia; $\mathrm{CE}=$ Ceará; $\mathrm{MA}=$ Maranhão; $\mathrm{PA}=$ Pará; $\mathrm{PB}=$ Paraíba; $\mathrm{PE}=$ Pernambuco; $\mathrm{RO}=$ Rondonia; $\mathrm{RR}=$ Roraima; $\mathrm{SE}=$ Sergipe; $\mathrm{TO}=$ Tocantins). The distribution map was created with the assistance of the Quantum Gis Program (2018). The other analyzes were performed with the SigmaPlot 14.0 program (2017)

\section{RESULTS AND DISCUSSION}

In 1900, no species of earthworms were described from the North and Northeast. Only two exotic species, Amynthas gracilis (Kinberg, 1867) and Amynthas pallidus (Michaelsen, 1892) were recorded for the State of Amazonas. Both species were reported by Rosa (1894). It is important to note that in this period Brazil did not have an active earthworm taxonomist, which may explain the low number of species records.

Over the next four decades the taxonomy of earthworms in the North and Northeast signalled a slight advance. During this period 19 new species were recorded, of which 18 were native (Table 1). However, until that time, Brazil as a whole had no active taxonomists, and all records of these four decades were only possible thanks to Michaelsen $(1918,1926,1928,1934)$ and Cernosvitov (1934, 1935, 1939). Importantly, despite progress, taxonomy was advancing at a rate of approximately 0.4 species per year. By the end of these four decades only six of the sixteen states that make up the North and Northeast had recorded earthworm species.

In the following period, which spans from 1941 to 1980, the advance was much higher compared to the previous period. In all, 73 new species were recorded for the North and Northeast of Brazil, 58 of which were native (Table 2). This period is also marked by the emergence of Gilberto Righi, today considered the greatest earthworm taxonomist in Brazil (Fragoso et al., 2003). Righi was responsible for the description of 50 of the 58 native species recorded in this period. This corresponds to almost $90 \%$ of the species. In addition, all exotic species were reported by him. This only further emphasizes his importance for Brazilian earthworm taxonomy.

In the last period, from 1981 to 2018, the number of species recorded was slightly higher than in the previous 
Table 2. Earthworm species recorded in the period 1941-1980 in the North and Northeast of Brazil.

\begin{tabular}{|c|c|c|c|c|}
\hline Species & State & Native/Exotic & Author & Reference \\
\hline Amynthas morrisi & $B A$ & Exotic & Beddard, 1892 & Righi, 1971 \\
\hline Andiorrhinus amazonius & AM & Native & Michaelsen, 1918 & Righi et al., 1976 \\
\hline Andiorrhinus tarumanis & $A M, R R$ & Native & Righi et al., 1976 & Righi et al., 1976 \\
\hline Andiodrilus icomi & $\mathrm{AM}, \mathrm{AP}$ & Native & Righi, 1971 & Righi, 1971; Righi et al., 1976 \\
\hline Areco reco & $A M$ & Native & Righi et al., 1978 & Righi et al., 1978 \\
\hline Atatina gatesi & $\mathrm{AM}$ & Native & Righi et al., 1978 & Righi et al., 1978 \\
\hline Atatina puba & PA & Native & Righi, 1971 & Righi, 1971 \\
\hline Bauba santosi & SE & Native & Righi, 1980a & Righi, 1980a \\
\hline Brinkhurstia americana & $A M$ & Exotic & Brinkhurst, 1964 & Righi et al., 1978 \\
\hline Cirodrilus angeloi & AP & Native & Righi, 1975 & Righi, 1975 \\
\hline Dariodrilus ferrarius & $A M$ & Native & Righi et al., 1978 & Righi et al., 1978 \\
\hline Diachaeta atroaris & AM & Native & Righi et al., 1978 & Righi et al., 1978 \\
\hline Diachaeta xecatu & $\mathrm{AM}$ & Native & Righi et al., 1978 & Righi et al., 1978 \\
\hline Diachaeta juli & AM & Native & Righi et al., 1978 & Righi et al., 1978 \\
\hline Diachaetania & AM & Native & Righi et al., 1976 & Righi et al., 1976 \\
\hline Dichogaster affinis & $A M, B A$ & Exotic & Michaelsen, 1890 & Righi, 1971; Righi et al., 1978 \\
\hline Dichogaster annae & BA & Exotic & Horst, 1883 & Righi, 1968a \\
\hline Dichogaster andina & $A M, P A$ & Exotic & Cognetti, 1904 & Righi et al., 1978 \\
\hline Dichogaster badajos & AM & Native & Righi et al., 1978 & Righi et al., 1978 \\
\hline Dichogaster ibaia & AM & Native & Righi et al., 1978 & Righi et al., 1978 \\
\hline Dichogaster modiglianii & AM & Exotic & Rosa, 1896 & Righi et al., 1978 \\
\hline Dichogaster saliens & $A M, B A, M A$ & Exotic & Beddard, 1893 & Righi, 1971, 1972; Righi et al., 1978 \\
\hline Eudrilus eugeniae & $\mathrm{BA}, \mathrm{MA}, \mathrm{PA}, \mathrm{PE}, \mathrm{SE}$ & Exotic & Kinberg, 1867 & Righi, 1967b, 1972 \\
\hline Eukerria asilis & $P A, P E$ & Native & Righi, 1968b & Righi, 1968b, 1971 \\
\hline Eukerria guamais & $A M, P A$ & Native & Righi, 1971 & Righi, 1971; Righi et al., 1978 \\
\hline Eukerria urna & BA & Native & Righi, 1968b & Righi, 1971 \\
\hline Eukerria taisa & PA & Native & Righi, 1983 & Righi, 1971 \\
\hline Exisdrilus rarus & AM & Native & Righi et al., 1978 & Righi et al., 1978 \\
\hline Glossodrilus geayi & AP & Native & Cernosvitov, 1934 & Righi, 1971 \\
\hline Glossodrilus antunesi & AP, MA & Native & Righi, 1971 & Righi, 1971, 1972 \\
\hline Hyperiodrilus africanus & PE & Exotic & Beddard, 1891 & Righi, 1972 \\
\hline Holoscolex caramuru & $\mathrm{AM}, \mathrm{AP}$ & Native & Righi, 1975 & Righi, 1995, 1978 \\
\hline Holoscolex nemorosus tacoa & $\mathrm{AM}$ & Native & Righi et al., 1978 & Righi et al., 1978 \\
\hline Haplodrilus tagua & AM & Native & Righi et al., 1978 & Righi et al., 1978 \\
\hline Liodrilusipu & PA & Native & Righi, 1975 & Righi, 1975 \\
\hline Martiodrilus duodenarius & AP & Native & Michaelsen, 1918 & Righi, 1971 \\
\hline Martiodrilus matapi & AP & Native & Righi, 1969 & Righi, 1971 \\
\hline Metaphire californica & BA & Exotic & Kinberg, 1867 & Righi, 1971 \\
\hline Meroscolex marcusi & AM & Native & Righi \& Ayres, 1976 & Righi \& Ayres, 1976 \\
\hline Meroscolex eudoxiae & $A M$ & Native & Righi et al., 1978 & Righi et al., 1978 \\
\hline Nematogenia panamaensis & BA & Exotic & Eisen, 1900 & Brown \& James, 2007 \\
\hline Neogaster gavrilovi & AP & Native & Righi \& Caballero, 1970 & Righi \& Caballero, 1970 \\
\hline Neogaster aidae & AP & Native & Righi, 1975 & Righi, 1975 \\
\hline Nouraguesia amaparis & AP & Native & Righi, 1971 & Righi, 1971 \\
\hline Omodeoscolex divergens & AM & Native & Cognetti, 1905 & Righi, 1978 \\
\hline Onychochaeta serieia & TO & Native & Righi, 1971 & Righi, 1971 \\
\hline Pickfordia tocaya & $\mathrm{AM}$ & Exotic & Righi et al., 1978 & Righi et al., 1978 \\
\hline Polypheretima elongata & $B A, P E$ & Exotic & Perrier, 1872 & Righi, 1971, 1980b \\
\hline Pontoscolex corethrurus & $\mathrm{AM}, \mathrm{AP}, \mathrm{PA}, \mathrm{PE}$ & Exotic & Müller, 1857 & Righi, 1967a \\
\hline Pontodrilus litoralis & $\mathrm{PE}$ & Exotic & Grube, 1855 & Brown \& James, 2007 \\
\hline Rhinodrilus adelae & CE & Native & Cordero, 1943 & Cordero, 1943 \\
\hline Rhinodrilus mamita & CE & Native & Cordero, 1943 & Cordero, 1943 \\
\hline Rhinodrilus lucilleae & $A M$ & Native & Righi et al., 1976 & Righi et al., 1976 \\
\hline Rhinodrilus priollii & AM & Native & Righi, 1967a & Righi, 1967a \\
\hline Rhinodrilus bursiferus & AP & Native & Righi, 1971 & Righi, 1971 \\
\hline Rhinodrilus curiosus & $\mathrm{AM}$ & Native & Righi et al., 1976 & Righi et al., 1976 \\
\hline Rhinodrilus motucu & $B A$ & Native & Righi, 1971 & Righi, 1971 \\
\hline Rhinodrilus francisci & $\mathrm{PE}$ & Native & Cordero, 1944 & Cordero, 1944 \\
\hline Rhinodrilus panxin & PA & Native & Righi, 1971 & Righi, 1971 \\
\hline
\end{tabular}




\begin{tabular}{|c|c|c|c|c|}
\hline Species & State & Native/Exotic & Author & Reference \\
\hline Righiodrilus aioca & $A P$ & Native & Righi, 1975 & Righi, 1975 \\
\hline Righiodrilus freitasi & AP & Native & Righi, 1971 & Righi, 1971 \\
\hline Righiodrilus marcusae & PA & Native & Righi, 1969 & Righi, 1969 \\
\hline Righiodrilus mucupois & AP & Native & Righi, 1970 & Righi, 1970 \\
\hline Righiodrilus cigges & AP & Native & Righi, 1970 & Righi, 1970 \\
\hline Righiodrilus schubarti & AM & Native & Righi et al., 1978 & Righi et al., 1978 \\
\hline Righiodrilus sucunduris & AM & Native & Righi et al., 1976 & Righi et al., 1976 \\
\hline Righiodrilus tinga & AP & Native & Righi, 1971 & Righi, 1971 \\
\hline Righiodrilus tocantinensis & PA & Native & Righi, 1972 & Righi, 1972 \\
\hline Tiguassu reginae & AM & Native & Righi et al., 1978 & Righi et al., 1978 \\
\hline Tuiba dianae & AM & Native & Righi et al., 1976 & Righi et al., 1976 \\
\hline Urobenus gitus & PA & Native & Righi, 1971 & Righi, 1971 \\
\hline Urobenus buritis & AM & Native & Righi et al., 1976 & Righi et al., 1976 \\
\hline Wegeneriona cernosvitovi & AP & Native & Righi \& Caballero, 1970 & Righi \& Caballero, 1970 \\
\hline
\end{tabular}

period. In all, 80 new species were recorded, 70 of them native (Table 3). From the beginning to the middle of this period, Righi still remains predominant in Brazilian taxonomy, being responsible for the description of 49 of the 70 native species recorded. With Righi's death in 1999, Brazilian taxonomy suffered a great loss, which was reflected in the following decade, where only one species was described in Brazil. In the North and Northeast region, earthworm taxonomy only resumed walking, even if at a slow stride, in the last two years, with the description of nine new species and two new genera. The data only highlights the importance and impact that the presence of only one taxonomist can have for a given region.

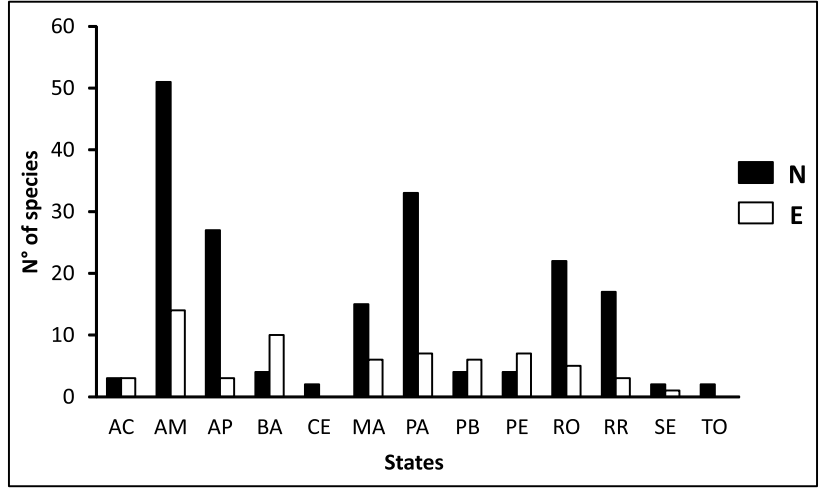

Figure 1. Native $(\mathrm{N})$ and exotic $(\mathrm{E})$ species numbers recorded in each state.

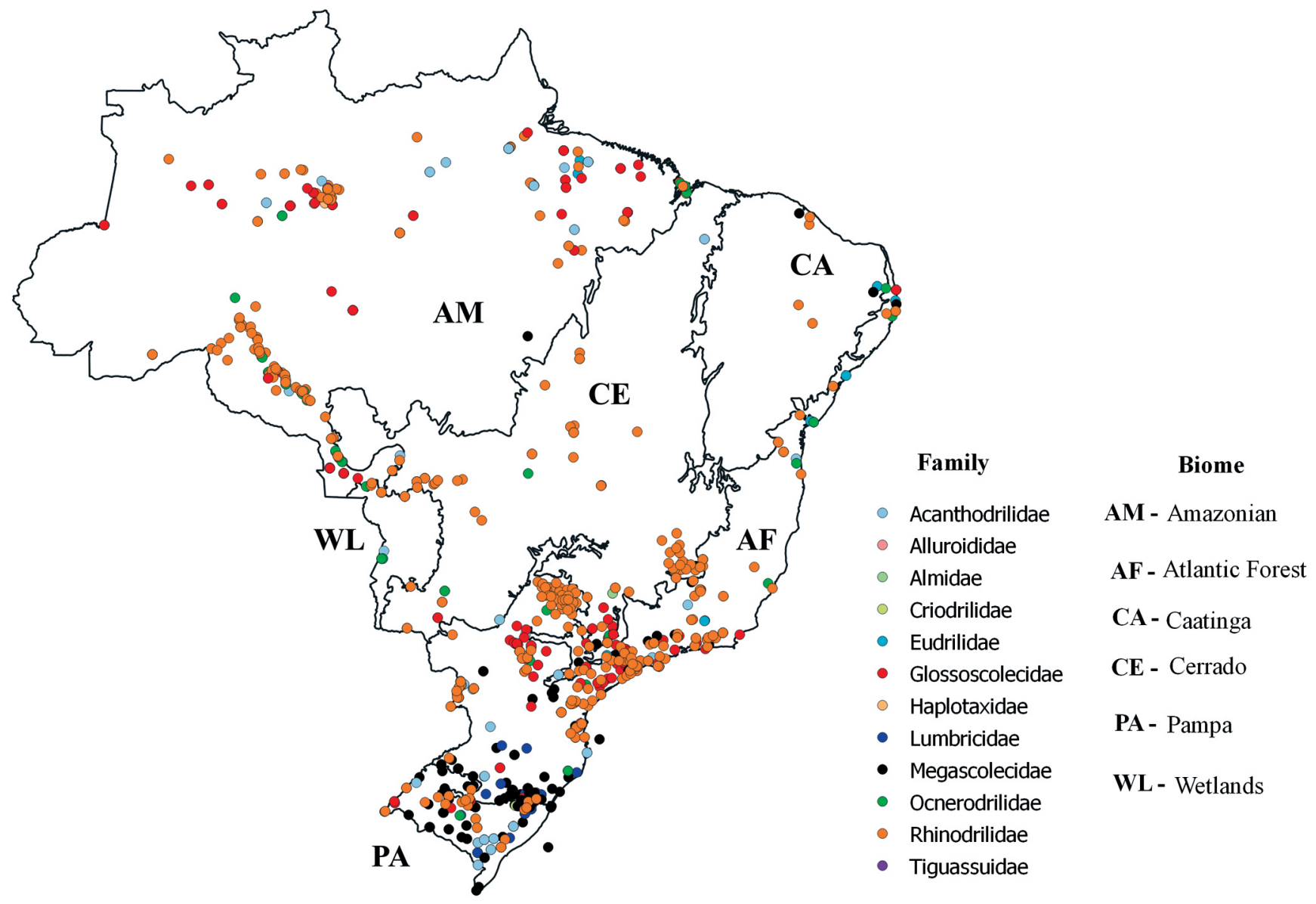

Figure 2. Distribution of earthworm families in Brazilian biomes. 
Table 3. Earthworm species recorded in the period 1981-2018 in the North and Northeast of Brazil.

\begin{tabular}{|c|c|c|c|c|}
\hline Species & State & Native/Exotic & Author & Reference \\
\hline Amynthas robustus & PB & Exotic & Perrier, 1872 & De Assis et al., 2017 \\
\hline Andiorrhinus caudatus & $\mathrm{AM}, \mathrm{PA}, \mathrm{RO}$ & Native & Righi et al., 1976 & Adis \& Righi, 1989; Righi, 1982a, 1986a \\
\hline Andiorrhinus evelineae & RO & Native & Righi, 1986a & Righi, 1986a \\
\hline Andiorrhinus holmgreni & RO & Native & Michaelsen, 1918 & Righi, 1986a \\
\hline Andiorrhinus pauate & RO & Native & Righi, 1986a & Righi, 1985 \\
\hline Andiorrhinus rondoniensis & RO & Native & Righi, 1986a & Righi, 1986a \\
\hline Andiorrhinus samuelensis & RO & Native & Righi, 1986a & Righi, 1985 \\
\hline Andiorrhinus (Turedrilus) miricuri & MA & Native & Hernández-García et al., 2018c & Hernández-García et al., 2018c \\
\hline Andiorrhinus (Turedrilus) barrosoi & MA & Native & Hernández-García et al., 2018c & Hernández-García et al., 2018c \\
\hline Andiorrhinus rodriguezi & AM & Native & Feijoo et al., 2017 & Feijoo et al., 2017 \\
\hline Anteoides pigy & $\mathrm{PA}$ & Native & Righi, 1982a & Righi, 1982a \\
\hline Arraia nelmae & MA & Native & Hernández-García et al., 2018b & Hernández-García et al., 2018b \\
\hline Brasilisia punki & MA & Native & Hernández-García et al., 2018b & Hernández-García et al., 2018b \\
\hline Cirodrilus aidae & PB & Native & Righi, 1994 & Righi, 1994 \\
\hline Cirodrilus righii & AM & Native & Zicsi et al., 2001 & Zicsi et al., 2001 \\
\hline Chibuibari & $A C$ & Native & Righi \& Guerra, 1985 & Righi \& Guerra, 1985 \\
\hline Diaguita vivianeae & AM & Exotic & Righi, 1984 & Righi, 1988b \\
\hline Diachaeta adisi & AM & Native & Righi, 1989a & Righi, 1989a \\
\hline Diachaeta arawak & AM & Native & Righi, 1989a & Righi, 1989a \\
\hline Diachaeta aceoca & PA & Native & Righi, 1982a & Righi, 1982a \\
\hline Diachaeta adnae & RO & Native & Righi, 1989a & Righi, 1989a \\
\hline Diachaeta mura & AM & Native & Righi, 1989b & Righi, 1989b \\
\hline Dichogaster modiglianii & RR & Exotic & Rosa, 1896 & Righi \& Guerra, 1985 \\
\hline Dichogaster saliens & $\mathrm{PA}, \mathrm{RO}$ & Exotic & Beddard, 1893 & Righi, 1988b, 1990 \\
\hline Dichogaster gracilis & $\mathrm{AM}, \mathrm{PB}, \mathrm{RO}$ & Exotic & Michaelsen, 1892 & Righi, 1990 \\
\hline Eukerria eiseniana & $\mathrm{RO}, \mathrm{RR}$ & Native & Rosa, 1895 & Righi, 1984, 1986b \\
\hline Eukerria subandina & RO & Native & Rosa, 1895 & Righi, 1986b \\
\hline Eukerria kuekenthali & $A M$ & Exotic & Michaelsen, 1908 & Righi, 1988b \\
\hline Eukerria mиси & RO & Native & Righi, 1988a & Righi, 1988a \\
\hline Goiascolex cabrelli & RO & Native & Righi, 1971 & Righi, 1986b \\
\hline Goiascolex edgardi & RO & Native & Righi, 1986b & Righi, 1986b \\
\hline Goiascolex pepus & $\mathrm{TO}, \mathrm{RO}$ & Native & Righi, 1972 & Righi, 1986b, 1990 \\
\hline Gordiodrilus habessinus & RO & Native & Michaelsen, 1913 & Righi, 1988a; Righi \& Guerra, 1985 \\
\hline Glossodrilus baiuca & RR & Native & Hamoui \& Donatelli, 1983 & Hamoui \& Donatelli, 1983 \\
\hline Glossodrilus motu & RR & Native & Righi, 1990 & Righi, 1990 \\
\hline Holoscolex dossantosi & MA & Native & Hernández-García et al., 2018a & Hernández-García et al., 2018a \\
\hline Holoscolex alatus & MA & Native & Hernández-García et al., 2018a & Hernández-García et al., 2018a \\
\hline Holoscolex fernandoi & MA & Native & Hernández-García et al., 2018a & Hernández-García et al., 2018a \\
\hline Haplodrilus amazonicus & AM & Native & Righi, 1983 & Righi, 1983 \\
\hline Liodrilus mendesi & $M A, P B$ & Native & Righi, 1994 & Righi, 1994; Sousa et al., 2020* \\
\hline Lourdesia paraibaensis & $P B$ & Native & Righi, 1994 & Righi, 1994 \\
\hline Meroscolex roraimensis & RR & Native & Righi, 1984 & Righi, 1990 \\
\hline Metataxis bare & RR & Native & Righi, 1988b & Righi, 1988b \\
\hline Nematogenia lacuum & RO & Exotic & Beddard, 1893 & Righi, 1984, 1988a \\
\hline Neogaster angeloi & AP & Native & Righi, 1988b & Righi, 1988b \\
\hline Ocnerodrilus occidentalis & $A M, P A$ & Exotic & Eisen, 1878 & Righi, 1988b \\
\hline Ocnerodrilus potyuara & PB & Exotic & Righi, 1994 & Righi, 1994 \\
\hline Omodeoscolex divergens & PA & Native & Cognetti, 1905 & Righi, 1984, 1989b \\
\hline Pithemera bicincta & PB & Exotic & Perrier, 1875 & De Assis et al., 2017 \\
\hline Pontoscolex cuasi & $A P, P A, R R$ & Native & Righi, 1984 & Righi, 1984, 1988b, 1990, 1998 \\
\hline Pontoscolex maracaensis & RR & Native & Righi, 1984 & Righi, 1984 \\
\hline Pontoscolex nogueirai & $P A, R R$ & Native & Righi, 1984 & Zicsi \& Csuzdi, 1999 \\
\hline Pontoscolex franzi & PA & Native & Zicsi \& Csuzdi, 1999 & Zicsi \& Csuzdi, 1999 \\
\hline Pontoscolex vandersleeni & AM & Native & Michaelsen, 1933 & Zicsi et al., 2001 \\
\hline Pontoscolex pydanieli & RO & Native & Righi, 1988a & Righi, 1988a, 1990 \\
\hline Pygmaeodrilus amapaensis & AP & Native & Righi, 1988b & Righi, 1988b \\
\hline Rhinodrilus jucundus & PA & Native & Righi, 1985 & Righi, 1985, 1989b \\
\hline Rhinodrilus pitun & $\mathrm{PE}$ & Native & Righi \& Moraes, 1990 & Righi \& Moraes, 1990 \\
\hline Rhinodrilus contortus & AM & Native & Cernosvitov, 1938 & Zicsi et al., 2001 \\
\hline
\end{tabular}




\begin{tabular}{|c|c|c|c|c|}
\hline Species & State & Native/Exotic & Author & Reference \\
\hline Rhinodrilus elisianae & $\mathrm{AM}, \mathrm{PA}, \mathrm{RO}$ & Native & Righi et al., 1976 & Zicsi \& Csuzdi, 1999; Righi, 1986b, 1988a, 1990 \\
\hline Rhinodrilus lourdesae & RO & Native & Righi, 1986b & Righi, 1986b \\
\hline Rhinodrilus marcusae & BA & Native & Righi, 1985 & Righi, 1985 \\
\hline Righiodrilus amazonius & PA & Native & Zicsi \& Csuzdi, 1999 & Zicsi \& Csuzdi, 1999 \\
\hline Righiodrilus arapaco & RR & Native & Righi, 1982b & Righi, 1982b \\
\hline Righiodrilus oliveirae & RR & Native & Righi, 1982b & Righi, 1982b, 1998 \\
\hline Righiodrilus dithecae & AP & Native & Righi, 1988b & Righi, 1988b \\
\hline Righiodrilus moju & PA & Native & Santos et al., 2017 & Santos et al., 2017 \\
\hline Righiodrilus gurupi & MA & Native & Santos et al., 2017 & Santos et al., 2017 \\
\hline Righiodrilus tico & $A M, R R$ & Native & Righi, 1982b & Righi, 1982b, 1988b, 1998 \\
\hline Righiodrilus venancioi & $A M, P A$ & Native & Righi, 1982a & Righi, 1982a \\
\hline Righiodrilus viseuensis & PA & Native & Santos et al., 2017 & Santos et al., 2017 \\
\hline Righiodrilus mairaro & RR & Native & Righi, 1982b & Righi, 1982b \\
\hline Righiodrilus uete & RO & Native & Righi, 1988a & Righi, 1988a \\
\hline Righiodrilus fontebonensis & AM & Native & Righi, 1988b & Righi, 1988b \\
\hline Righiodrilus ortonae & PA & Native & Righi, 1988b & Righi, 1988b \\
\hline Righiodrilus dithecae & AP & Native & Righi, 1988b & Righi, 1988b \\
\hline Urobenus petrerei & $M A, P A$ & Native & Righi, 1985 & Righi, 1985 \\
\hline Urobenus igpigpuera & $\mathrm{PA}$ & Native & Righi, 1982a & Righi, 1982a \\
\hline Urobenus brasiliensis & $A M, M A, P A$ & Native & Benham, 1887 & Römbke et al., 1999; Righi, 1985 \\
\hline Wegeneriona belenensis & PA & Native & Righi, 1988b & Righi, 1988b \\
\hline
\end{tabular}

* Sousa et al., $2020 *$ is still in the process of being published.

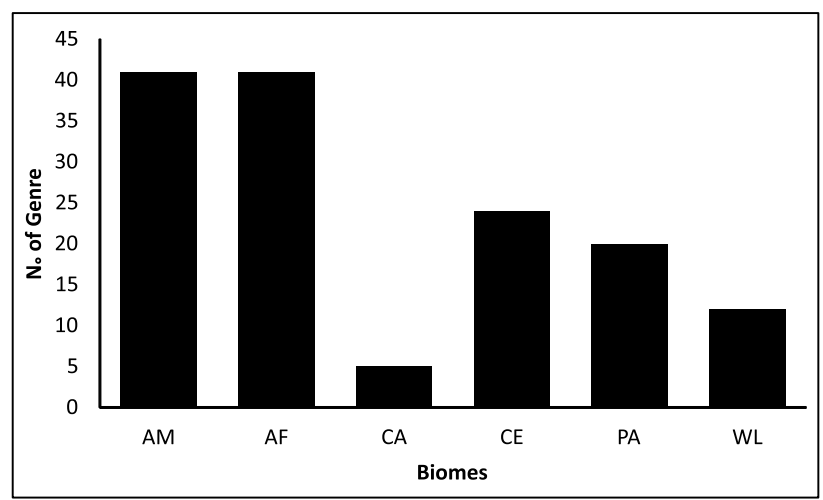

Figure 3. Number of genera in each Brazilian biome.

After a century, three of the sixteen states that make up the North and Northeast of Brazil (Alagoas, Piauí and Rio Grande do Norte) do not yet have any earthworm recorded. The states with the largest number of species are Amazonas (AM), Pará (PA) and Amapá (AP), while Ceará (CE), Tocantins (TO) and Sergipe (SE) have the lowest numbers (Fig. 1).

The states of Bahia (BA), Paraíba (PB) and Pernambuco $(P E)$ stand out for being the only ones with more exotic than native species (Fig. 1), while Amazonas is the one with the largest number of native species.

Regarding distribution, there are twelve families of earthworms distributed in six Brazilian biomes, with Acanthodrilidae, Ocnerodrilidae and Rhinodrilidae being the only ones present in all biomes (Fig. 2). Glossoscolecidae, Megascolecidae and Rhinodrilidae also stand out for their abundance in the Brazilian territory. Attention is drawn to the distribution of the family Megascolecidae, which is more abundant in southern Brazil (Fig. 2).

In relation to earthworm genera, 82 are found within the six biomes. The Amazonian and Atlantic Forest bi-

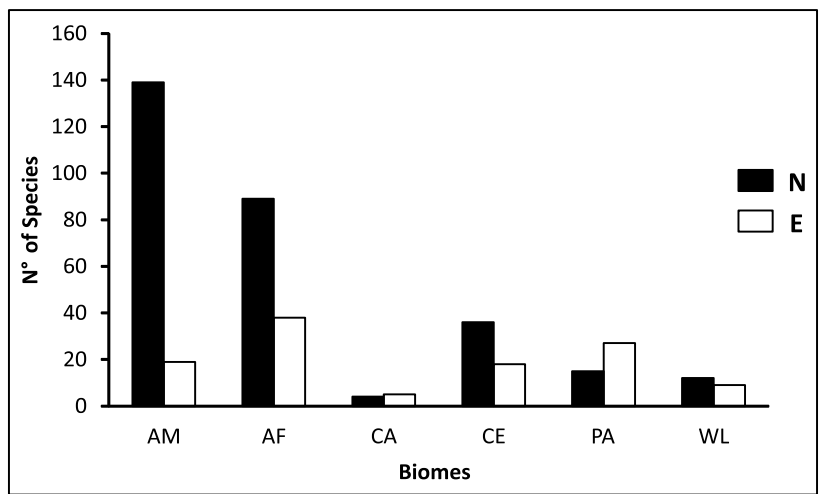

Figure 4. Number of native (N) and exotic (E) species in Brazilian biomes.

omes stand out because they represent more than half of the genera found in Brazilian soil (Fig. 3), while in the Caatinga biome only five earthworm genera are found, being the poorest in genera of the six biomes.

Among all biomes, Caatinga and Pampa are the only ones that have more exotic than native species (Fig. 4), which may be an indication that these biomes are undergoing environmental degradation processes. On the other hand, this result may be correlated with the small number of studies with earthworms, a factor that is related to the low level of active taxonomy in Brazil. As for the Brazilian Wetland, more than $40 \%$ of the species found are exotic. As expected, the Amazonian and Atlantic Forest biomes are the ones that hold the largest number of earthworm species, most of which are native species. This result highlights the richness of these two biomes in particular, and the attention that these two biomes should receive regarding to the conservation of native species.

It is important to emphasize that native species of earthworms are sensitive to anthropic disturbances (Winsome et al., 2006), and in some cases can be elimi- 
nated by exotic species (Pop \& Pop, 2006). Thus measures aimed at the conservation of these biomes are of utmost importance for the conservation of these native species and of the possible new species that have not yet been described.

\section{CONCLUSION}

In the first decades after 1900, the taxonomy of earthworms in the North and Northeast advanced slowly, mainly due to the absence of active specialists in this period. The greatest advance was made between the 60's and 90's, which corresponds to the period of Gilberto Righi's works. There are currently 174 species distributed in 13 states of the North and Northeast of Brazil. Earthworms can be found in all Brazilian biomes, with the families Rhinodrilidae, Megascolecidae and Glossoscolecidae being the most representative. The Amazonian and Atlantic Forest biomes stand out for their great biodiversity of earthworms, while the Cerrado presents intermediate values both at the level of families and in genera and species. It is important to emphasize that this work is only a small step towards the better knowledge of this group of organisms. Of utmost importance, and yet often "despised", this group may be taken as a basis for future work on this topic.

\section{ACKNOWLEDGMENTS}

We appreciate all the support provided by the State University of Maranhão and by the Federal University of Paraiba. We appreciate the support of all students involved in the development of this work.

\section{REFERENCES}

Adis, J. \& Righi, G. 1989. Mass migration and life cycle adaptation - a survival strategy of terrestrial earthworms in Central Amazonian inundation forest. Amazoniana, 11: 23-30.

Beddard, F.E. 1891. On the Structure of Two New Genera of Earthworms belonging to the Eudrilidae and some Remarks on Nemertodrilus. Quarterly Journal of Microscopical Science, 32: 235-278.

Beddard, F.E. 1892. The earthworms of the Vienna Museum. The Annals and Magazine of Natural History, Serie 6, 9: 113-134.

Beddard, F.E. 1893. Two new genera and some new species of earthworms. Quarterly Journal of Microscopical Science, 34: 243-278.

Benham, W.B. 1887. Studies on earthworms. № II. Quarterly Journal of Microcopical Science, 27: 77-108.

Brinkhurst, R.0. 1964. A taxonomic revision of the Alluroididae (Oligochaeta). Proceedings of the Zoological Society of London, 142: 527-536.

Brown, G.G. \& James, S.W. 2007. Biodiversidade, biogeografia e ecologia das minhocas no Brasil. In: Brown, G.G. \& Fragoso, C. (Eds.). Minhocas na América Latina: biodiversidade e ecologia. Londrina, Embrapa Soja, p. 297-381.

Cernosvitov, L. 1934. Les Oligochètes de la Guyane Française et d'autres pays de l'Amérique du Sud. Bulletin du Musée Nationale d'Histoire Naturelle de Paris, 2: 47-59.
Cernosvitov, L. 1935. Oligochaeten aus dem tropischen Sud Amerika. Capita Zoologica, 6: 1-36.

Cernosvitov, L. 1938. Deux nouveaux Oligochétes Glossoscolecides du Brésil. Bulletin de l'Association Philomathique d'Alsace et de Lorraine, 8: 401-407.

Cernosvitov, L. 1939. Résultats scientifiques des croisières du navire-école Belge "Mercator", Vol. 2. VII. Oligochaeta. Musée Royal d'Histoire Naturelle de Belgique, 2ème Serie, 15: 115-122.

Cognetti de Martiis, L. 1902. Un nuovo genere della fam. "Glossoscolecidae". Ricerche anatomiche e zoologiche. Atti della Reale Accademie delle Scienze di Torino, 37: 432-446.

Cognetti de Martiis, L. 1904. Oligocheti dell'Ecuador. Bollettino dei Musei di Zoologia ed Anatomia Comparata della Reale Università di Torino, 19: 1-18.

Cognetti de Martiis, L. 1905. Gli Oligocheti dela regione neotropicale, Parte Prima. Memorie della Accademia Reale delle Scienze di Torino, Serie 2, 55 : 1-72.

Cordero, E.H. 1943. Oligoquetos sudamericanos de la familia Glossoscolecidae. II - Dos nuevas especies de Rhinodrilus del nordeste del Brasil. Comunicaciones Zoológicas del Museo de Historia Natural de Montevideo, 1(6): 1-6.

Cordero, E.H. 1944. Oligoquetos sudamericanos de la família Glossoscolecidae, III. Rinodrilus francisci n. sp. de Pernambuco, Brasil. Comunicaciones Zoológicas del Museo de Historia Natural de Montevideo, 10: 1-4.

Coutinho, L.M. 2006. 0 conceito de bioma. Acta Botanica Brasilica, Belo Horizonte, 20: 13-23.

Darwin, C. 1881. The formation of vegetable Mould through the action of Worms with observations on their habits. London, John Murray. 326p.

De Assis, J.E.; Souza, J.R.B.; Vieira, M.L.M.; Nunes De Souza, J.V.; Rodrigues, G.G. \& Christoffersen, M.L. 2017. A catalogue of the Eudrilidae and Megascolecidae (Clitellata: Lumbricina) from South America, with two new records of exotic species from Brazil. Turkish Journal of Zoology, 41: 599-614.

Eisen, G. 1878. On the anatomy of Ocnerodrilus. Nova Acta Regiae Societatis Scientiarum Upsaliensis, 10(3): 1-12.

Eisen, G. 1900. Researches in the American Oligochaeta with special reference to those of the Pacific Coast and Adjacent Island. Proceedings of the California Academy of Sciences, 2(3): 85-276.

Feijo0, A.M.; Brown, G.G. \& James, S.W. 2017. New species of Andiorrhinus Cognetti, 1908 (Oligochaeta: Rhinodrilidae) from Venezuela and Brazil. Zootaxa, 4363(1): 055-078.

Fragoso, C.; Brown, G.G. \& Feijoo, A.M. 2003. The influence of Gilberto Righi on tropical earthworm taxonomy: The value of a full-time taxonomist. Pedobiologia, 47: 400-404.

Grube, A.E. 1855. Beschreibungen neuer oder wenig bekannter Anneliden. Archiv für Naturgeschichte, 21(1): 81-136.

Hamoui, V. \& Donatelli, R.J. 1983. Uma espécie nova de Oligochaeta, lossoscolecidae, Glossodrilus (G.) baiuca, n. sp., from the territory of Roraima, Brasil. Revista Brasileira de Biologia, 43: 143-146.

Hernández-García, L.M.; Burgos-Guerrero, J.E.; Santos, B.T.S.; Rousseau, G.X. \& James, S.W. 2018a. Three new species of Holoscolex (Clitellata, Glossoscolecidae) from the Gurupi Biological Reserve, last forest remnant of the Belém Endemism Area, Eastern Amazon. Zootaxa, 4496(1): 459-471.

Hernández-García, L.M.; Burgos-Guerrero, J.E.; Rousseau, G.X. \& James, S.W. 2018b. Brasilisia n. gen. and Arraia n. gen., two new genera of Ocnerodrilidae (Annelida, Clitellata, Oligochaeta) from Eastern Amazonia, Brazil. Zootaxa, 4496(1): 472-480.

Hernández-García, L.M.; Bartz, M.L.; Burgos-Guerrero, J.E.; Sousa, S.C.; Rousseau, G.X. \& James, S.W. 2018c. Additions to Andiorrhinus (Turedrilus) (Rhinodrilidae, Clitellata) from Eastern Amazonia. Zootaxa, 4496(1): 481-491. 
Horst, R. 1883. Note XVII. New species of the genus Megascolex Templeton (Perichaeta Schmarda) in the collections of the Leyden Museum. Notes from the Leyden Museum, 5: 182-196.

Jones, C.G.; Lawton, J.H. \& Shachak, M. 1994. Organisms as ecosystem engineers. Oikos, 69: 373-386.

Kinberg, J.G.H. 1867. Annulata nova. Ofversigt af Kongliga VetenskapsAkademiens Forhandlingar, Stockholm, 23: 97-103.

Michaelsen, W. 1890. Oligochaeten des Hamburger Naturhistorischen Museum. III. Mitteilungen aus dem Naturhistorischen Museum in Hamburg, 7: 1-12.

Michaelsen, W. 1891. Terricolen der Berliner Zoologischen Sammlung. I. Afrika. Archiv für Naturgeschichte, 57: 205-228.

Michaelsen, W. 1892. Terricolen der Berliner Zoologischen Sammlung, II. Archiv für Naturgeschiechte, 58: 209-261.

Michaelsen, W. 1900. Das Tierreich. Oligochaeta. Berlin, Friedländer \& Sohn. v. 10,575 p.

Michaelsen, W. 1908. Die Oligochäten Westindiens. Zoologische Jahrbücher, Abteilung für Systematik, 11: 13-32.

Michaelsen, W. 1913. Oligochäten vom tropischen und südlich-subtropischen Afrika, II. Zoologica, Stuttgart, 26(68): 1-63.

Michaelsen, W. 1917. Die Lumbriciden. Zoologische Jahrbücher, Abteilung für Systematik, 41: 1-398.

Michaelsen, W. 1918. Die Lumbriciden, mit besonderer Berücksichtigung der Bisher als Familie Glossoscolecidae zusammengefassten Unterfamilien. Zoologische Jahrbücher, Abteilung für Systematik, 41: 1-398.

Michaelsen, W. 1926. Zur kenntnis einheimischer und ausländischer Oligochäten. Zoologische Jahrbücher, Abteilung für Systematik, 51: 255-328.

Michaelsen, W. 1927. Die Oligochatenfauna Brasiliens. Abhandlungen der Senckenbergischen Gesellschaft, 40: 367-375.

Michaelsen, W. 1928. Miscelanea oligochaetologica. Archiv för Zoologi, 20: 1-15.

Michaelsen, W. 1933. Die Oligochätenfauna Surinames, mit Erörterung der verwandschaftlichen und geographischen Beziehungen der Octochätinen. Tijdschrift der Nederlandsch Dierkunde Vereeniging, Leiden, 3(3): 112-131.

Michaelsen, W. 1934. Opisthopore oligochäten des königlichen naturhistorischen museums von Belgien. Bulletin du Musée Royal d'Histoire Naturelle de Belgique, 10: 1-29.

Müller, F. 1857. Description of a new species of earthworm (Lumbricus corethrurus). Annals and Magazine of Natural History, Serie 2, 20: 13-151.

Nascimento, D.T.F. \& Ribeiro, S.A. 2017. Os biomas brasileiros e a defesa da vida. Goiânia, Kelps. 46p.

0jha, R.B. \& Devkota, D. 2014. Earthworms: 'Soil and Ecosystem Engineers'-a Review. World Journal of Agricultural Research, 2: 257-260.

Perrier, E. 1872. Recherches pour servir a l'histoire des lombriciens terrestres. Nouvelles Archives du Muséum d'Histoire Naturelle, 8: 5-198.

Perrier, E. 1875. Sur les vers de terre des îles Philippines et de la Cochinchine. Comptes Rendus des Séances de l'Académie des Sciences, 81: 1043-1046.

Pop, V.V. \& Pop, A.A. 2006. Lumbricid earthworm invasion in the Carpathian Mountains and some other sites in Romania. Biological Invasions, 8: 1219-1222.

QGIS Development Team. 2018. QGIS Geographic Information System. Open Source Geospatial Foundation Project. http://qgis.osgeo.org.

Righi, G. 1967a. Descrição de Rhinodrilus priollii, sp. n., Glossoscolecidae da Amazônia, com bibliografia dos Oligochaeta Terricola da região. In: Atas do Simpósio sôbre a Biota Amazônica. Rio de Janeiro, CNPq. v. 5, p. 475-479.

Righi, G. 1967b. Eudrilus eugeniae (Kinberg, 1867). Oligochaeta terrícola novo para o Brasil. Ciência e Cultura, 19: 341-342.
Righi, G. 1968a. Considerações sobre 0 gênero Rhinodrilus (Oligochaeta, Glossoscolecidae). Atas II Congreso Brasileiro de Zoologia, A2-26.

Righi, G. 1968b. Sobre alguns Oligochaeta do Brasil. Revista Brasileira de Zoologia, 28: 369-382.

Righi, G. 1969. On some Brazilian Glossoscolecidae. Beitrage zur Neotropischel Fauna, 6: 152-162.

Righi, G. 1970. Sobre o gênero Andioscolex (Oligochaeta, Glossoscolecidae). Revista Brasileira Biologia, 30: 371-376.

Righi, G. 1971. Sobre a família Glossoscolecidae (Oligochaeta) no Brasil. Arquivos de Zoologia, 20: 1-96.

Righi, G. 1972. Contribuição ao conhecimento dos Oligochaeta brasileiros. Papéis Avulsos de Zoologia, 25: 148-166.

Righi, G. 1975. Some Oligochaeta from the Brazilian Amazônia. Studies on the Neotropical Fauna, 10(1): 77-95.

Righi, G. 1978. Notas sobre os Oligochaeta de Amazônia. Acta Amazonica, 8: 485-488.

Righi, G. 1980a. Alguns Oligochaeta, Ocnerodrilidae e Glossoscolecidae do Brasil. Papéis Avulsos de Zoologia, 33(13): 239-246.

Righi, G. 1980b. Alguns Megadrile (Oligochaeta, Annelida) brasileiros. Boletim de Zoologia, São Paulo, 5: 1-8.

Righi, G. 1982a. Oligochaeta, Glossoscolecidae do Parque Nacional da Amazônia, Tapajós. Revista Brasileira de Biologia, 42: 107-116.

Righi, G. 1982b. Adições ao gênero Glossodrilus (Oligochaeta, Glossoscolecidae). Revista Brasileira de Zoologia, 1: 55-64.

Righi, G. 1983. Três Ocnerodrilidae (Oligochaeta) da Amazônia brasileira. Acta Amazonica, 13: 927-936.

Righi, G. 1984. On a collection of Neotropical Megadrili Oligochaeta. I. Ocnerodrilidae, Acanthodrilidae, Octochaetidae, Megascolecidae. Studies on Neotropical Fauna and Environment, 19: 9-31.

Righi, G. 1985. Sobre Rhinodrilus e Urobenus (Oligochaeta, Glossoscolecidae). Boletim de Zoologia, São Paulo, 9: 231-257.

Righi, G. 1986a. Sobre o gênero Andiorrhinus (Oligochaeta, Glossoscolecidae). Boletim de Zoologia, São Paulo, 10: 123-151.

Righi, G. 1986b. Alguns Oligochaeta, Glossoscolecidae, de Rondônia, Brasil. Boletim de Zoologia, São Paulo, 10: 283-303.

Righi, G. 1988a. Adições à drilofauna de Rondônia, Brasil. Revista Brasileira de Zoologia, 48: 119-125.

Righi, G. 1988b. Uma coleção de Oligochaeta da Amazônia brasileira. Papéis Avulsos de Zoologia, 36: 337-351.

Righi, G. 1989a. Três Oligochaeta, Glossoscolecidae da Amazônia. Amazoniana, 10:393-399.

Righi, G. 1989b. Alguns Oligochaeta da Amazônia. Boletim do Museu Paraense Emilio Goeldi, 5: 3-8.

Righi, G. 1990. Oligochaeta da Estação Ecológica de Maracá, Roraima, Brasil. Acta Amazonica, 20: 391-398.

Righi, G. 1994. On new and old-known Oligochaeta genera from Paraíba State, Brazil. Revue Suisse de Zoologie, 101: 89-106.

Righi, G. 1995. A new earthworm (Ocnerodrilidae, Oligochaeta) from a Brazilian cave and considerations about Belladrilus. Revue Suisse de Zoologie, 102: 361-365.

Righi, G. 1998. Earthworms of the llha de Maracá. In: Milliken, W. \& Ratter, J. (Ed.). Maracá: the biodiversity and environment of an Amazonian rainforest. Chichester, John Wiley \& Sons. p. 391-397.

Righi, G. \& Ayres, I. 1976. Meroscolex marcusi, sp. n. Oligochaeta, Glossoscolecidae da Amazônia. Boletim de Zoologia, 1: 257-263.

Righi, G. \& Caballero, M.E.S. 1970. Duas espécies brasileiras dos gêneros Wegeneriona e Neogaster (Oligochaeta, Octochaetidae). Revista Brasileira de Biologia, 30: 91-96.

Righi, G. \& Guerra, A.T. 1985. Alguns Oligochaeta do norte e noroeste do Brasil. Boletim de Zoologia, 9: 145-157. 
Righi, G. \& Moraes, P.H.F. 1990. Rhinodrilus piton, sp. n. Oligochaeta, Glossoscolecidae de Pernambuco. Revista Brasileira de Zoologia, 50: 519-522.

Righi, G.; Ayres, I. \& Bittencourt, E.C.R. 1976. Glossoscolecidae (Oligochaeta) do Instituto Nacional de Pesquisas da Amazônia. Acta Amazonica, 6: 335-367.

Righi, G.; Ayres, I. \& Bittencourt, E.C.R. 1978. Oligochaeta (Annelida) do Instituto Nacional de Pesquisas da Amazônia. Acta Amazonica, 8: 1-49.

Römbke, J.; Meller, M. \& García, M. 1999. Earthworm densities in central Amazonian primary and secondary forests and a polyculture forestry plantation. Pedobiologia, 43: 518-522.

Rosa, D. 1894. Perichetini nuovi o meno noti. Atti della Reale Accademia delle Scienze di Torino, 29: 773.

Rosa, D. 1895. Viaggio del dottor Alfredo Borelli nella Repubblica Argentina e nel Paraguay XV. Oligocheti terricoli (inclusi quelli raccolti nel Paraguay dal Dr. Paul Jordan). Bollettino di Zoologia ed Anatomia Comparata della Reale Università di Torino, 10: 1-3.

Rosa, D. 1896. I lombrichi raccolti a Sumatra dal Dott. Elio Modigliani. Annali del Museo Civico Di Storia Naturale Di Genova, 16: 502-532.

Santos, B.T.S.; Bartz, L.M.; Hernández-García, L.M.; Rousseau, G.X.; Martins, M.B. \& James, S.W. 2017. New earthworm species of Righiodrilus (Clitellata, Glossoscolecidae) from eastern Amazonia. Zootaxa, 4242(2): 392-400.
Santos, T.0.; Filho, V.S.A.; Rocha, V.M. \& Menezes, J.S. 2017. Os impactos do desmatamento e queimadas de origem antrópica sobre o clima da Amazônia brasileira: Um estudo de revisão. Revista Geográfica Acadêmica, 11: 157-181.

SigmaPlot version 14.0. 2017. From Systat Software. Jose California USA, http://www.systatsoftware.com.

Silva, P.A.S.; Silva, T.S.; Varanda, T.S.; Albuquerque, A.R. \& Junior, A.P. 2018. Proposta de recuperação de área degradada por queimadas no município de Marabá, PA. Revista Brasileira de Gestão Ambiental, 12: 08-17.

Sousa, S.C.; Hernández-García, L.M.; Rousseau, G.X. In Press. A new species of Pontoscolex earthworm (Rhinodrilidae, Clitellata) from the Gurupi Biological Reserve, along with records of earthworm species from the Amazon region of Maranhão, Brazil. Zootaxa.

Walton, W.R. 1928. Earthworms as pests and otherwise. Farmer's Bulletin, U.S. Department of Agriculture, 569: 1-14.

Winsome, T.; Epstein, L.; Hendrix, P.F. \& Horwath, W.R. 2006. Competitive interactions between native and exotic earthworm species as influenced by habitat quality in a California grassland. Applied Soil Ecology, 32: 38-53.

Zicsi, A.\&Csuzdi,C. 1999. Neue und bekannte regenwürmer aus verschiedenen Teilen Südamerikas. Senckenbergiana Biologica, 78: 123-134.

Zicsi, A.; Rombke, J. \& Garcia, M. 2001. Regenwürmer (Oligochaeta) aus der Umgebung von Manaus (Amazonien). Revue Suisse de Zoologie, 108: 153-164. 